\title{
The Impact of Gelora Manahan Solo Renovation on Persis Solo Potential Sport Tourism
}

Febrianur Ibnu Fitroh Sukono Putra ${ }^{1 \bowtie}$, Diana Aqmala ${ }^{2}$, Aflit Nuryulia Praswati ${ }^{3}$

${ }^{1}$ Management, Faculty of Economics and Business, Dian Nuswantoro University, Indonesia

${ }^{2}$ Management, Faculty of Economics and Business, Dian Nuswantoro University, Indonesia

${ }^{3}$ Management, Faculty of Economics and Business, Muhammadiyah Surakarta University, Indonesia

\section{Article Information}

Article history:

Accepted: September 2020

Approved: January 2021

Published: March 2021

\section{Keywords:}

Football Sport

Persis Solo

SWOT Analysis

Special Interest Tourism

\begin{abstract}
Football is an extraordinary type of tourism in the sports sector which is very popular in the world, which the matches of football teams being tourist attraction objects that provide benefits for the organizers of the competition and the football club itself. Indonesian football competition has been participated by many professional teams, one of them is PERSIS Solo who participated in league 2. This research aims to analyze the potential interest in PERSIS Solo sports tourism in Surakarta after the renovation program of the Manahan Solo Stadium. This type of research is descriptive qualitative. The analysis method uses SWOT (strengths, weaknesses, opportunities, and threats). Internal environment analysis will focus on strengths and weaknesses, while the external environment will be the focus on opportunities and threats. The results showed that PERSIS Solo was in the quadrant I position, so the management of the club could take a policy with utilizing the strength of the internal environment to maximize existing market opportunities.
\end{abstract}

How to Cite: Putra, F., Aqmala, D., \& Praswati, A. (2021). The Impact of Gelora Manahan Solo Renovation on Persis Solo Potential Sport Tourism. Jurnal Penelitan Ekonomi dan Bisnis, 6(1), 45-57. doi: https://doi.org/10.33633/jpeb.v6i1.3753 


\section{INTRODUCTION}

Global tourism sector development entering the 21st century has experienced a shift in tourist's consumption patterns. The trend in the $80 \mathrm{~s}$ in Europe, tourists visiting destinations together in large numbers (mass tourism) through programs provided from tour and travel services (Abujamous et al., 2019). Along with the times, the consumption pattern of tourism nowadays is changing to tourism with a more specific desire or often called special interest tourism. Special interest tourism comes with the aim of satisfying tourists according to the specific wishes that have been planned, so they will pay more or give "tips" to the tour organizers so that emotional stimulation such as optimal and varied experiences is formed. The limited available time makes tourists not only want to buy a product but also want to buy a valuable taste and experience (Mandulangi \& Towoliu, 2019). The sports industry is one of the very important aspects and makes a significant contribution to economic development in a country. In various developed countries such as America, Britain, Germany, France, Italy, Korea, and China, sports have become one of the leading industries as a supplier of foreign exchange. Special interest tourism in the sports sector is a recreational experience that has a positive economic impact in various countries, based on research which shows that the contribution of sports to the gross domestic product in industrialized countries is between 1$2 \%$, while the contribution of tourism is between $4-6 \%$. Besides that, the sport has also been designed as a modern industry on a global scale. In building national character, the sport has become an industrial identity that authentically has added value and significant competitiveness (Seyidov \& Adomaitienè, 2017).

The type of sport that is very popular nowadays in the world is football. Football is a special attraction with various atmospheres in every match held, so the public interest to watch it is very high. In fact, not only a few people travel to other countries just to enliven football events. Several football events such as inter-club leagues until international competitions provide special experiences for tourists or supporters who are present to watch. These tourists' visits will certainly provide income for the organizers and the government concerned so that it has a positive economic impact (Rudkin \& Abhijit, 2017). Football is a major player in city development even up to country- level because football fans do not only have a small and compartmentalized scope but have a very wide range throughout the world. Two clubs from Manchester in England, for example, with football matches being held at both Manchester United's Old Trafford and Manchester City's Etihad Stadium, hotels in the city of Manchester have an average occupancy rate of $85 \%$, compared to non-match days of $70 \%$. Another example is when the Etihad Stadium holds a UEFA Champions League match between Manchester City and Spanish giants Real Madrid, the occupancy rate in the city of Manchester is at a level of 97\% (STR Global Occupancy Rates, 2016). In Manchester City, as reported, football being able to contribute in increasing promotion to foreign countries so that Manchester city becomes one of the tourist destinations must be visited when visiting England. Football also has a positive impact in the financial sector with a total value of $£ 330 \mathrm{~m}$ a year for the economy of Manchester city, with 8,500 jobs involved to support the sport. Tourist's consumption averages while watching matches in the Premier League up to $£ 856$ and gives a greater advantage to the country than inbound visitors from other countries to England who spend only $£ 626$ (Edrak et al., 2016).

In Indonesia, sports sector industry development still requires the active participation of the community to provide excellent sport (Sheng \& Chen, 2016). Nowadays, football in Indonesia has been joined by elite professional teams in all cities in Indonesia, one of which is PERSIS Solo based in Surakarta. PERSIS Solo is one of the biggest clubs in Indonesia, founded in 1923. Whenever there is a match at Manahan Solo, it can attract thousands of visits from supporters or tourists (event sport tourism). The average ticket sold in each PERSIS Solo match is up to 21,778 tickets (Sambernyawa, 2014). Even though it has a large supporter base whose presence has a positive impact on club income, PERSIS Solo still has obstacles, namely inconsistency in attracting more tourists visiting, this is due to the team's performance and operational expenses in competing not proportional upon the club's main source income which is from the audience ticket.

Table 1. Main Facilities Capacity Comparison for GBK Stadium and Manahan Stadium in Solo

\begin{tabular}{|c|c|c|c|}
\hline \multirow{2}{*}{ No } & \multirow{2}{*}{ FACILITIES } & \multicolumn{2}{|c|}{ CAPACITY } \\
\cline { 3 - 4 } & & GBK & MANAHAN SOLO \\
\hline 1 & Main stadium (soccer field) & 88.000 & 25.000 \\
\hline 2 & Aquatic stadium & 9.500 & 2.500 \\
\hline 3 & Velodrome & - & 500 \\
\hline 4 & Futsal court & - & 3.500 \\
\hline
\end{tabular}

Source: (Ismawati \& Astuti, 2020). 
Febrianur Ibnu Fitroh Sukono Putra, Diana Aqmala, Aflit Nuryulia Praswati: The Impact of Gelora Manahan Solo Renovation on Persis Solo Potential Sport Tourism

The data listed above shows several facilities in Manahan Stadium Solo complex compared to GBK complex, where venue ownership is more complete at Manahan Stadium Solo. This also shows that Manahan Stadium Solo has high potential to improve its quality to the international arena, however, it is necessary to improve capacity building sector in each venue. The U-20 World Cup which will be held in Indonesia provides an opportunity for all of the best stadium managers in the country to register their venue to support the event become successful. FIFA announced that Manahan Stadium Solo was chosen as one of the venues to hold the U-20 world cup competition which encouraged the city government of Surakarta to positively welcome the event because it could increase the competitiveness of Solo City, support cultural city tourism, and the proud football team it owns, PERSIS Solo. The preparations planned by the government are improving sports tourism destinations by renovating various owned venues and also inviting the PERSIS Solo team and their supporters to support these activities. Manahan Stadium Solo is also famous for organizing various events including League 1, League 2, international matches, athletic competitions, and various festivals.

A study conducted by Putri (2020) stated that sports development in a national sports system is developed through three pillars, namely educational sports, recreational sports, and achievement sports. Educational sports are an integral part of education which is carried out both in formal and non-formal paths through intra and or extracurricular activities. Recreational sports aim to develop public awareness to improve health, fitness, pleasure, and social relations, while achievement sports are devoted to achieving achievements in the district, national, regional, and international championships. Meanwhile, a study conducted by Rawe (2018) showed that sports facilities are an important component in supporting the implementation of an element of sports development. Without adequate sports facilities, it is difficult to expect society or public participation in sports activities. In a study conducted by Sivrikaya et al. (2018), it is found that sports infrastructure is every necessary thing for sports implementation activities in the form of buildings, fields, and equipment. Sports facilities and infrastructure are used in sports coaching, with complete facilities and infrastructure, sports coaching will be easier to do.

The urgency of this study is to contribute to the planning of the Surakarta City Government regarding the renovation program of the Manahan Stadium Solo as a form of venue selection and as an increase in the standard of ability to hold international matches. PERSIS Solo management should manage this positive issue to increase sports tourism and increase club finances so that they can continue to exist and compete in the national football industry because as we know, the club from Solo has long been in League 2. In the implementation of sport tourism, the government and public have the opportunity to work together in organizing sports events to improve tourism promotion programs in Indonesia generally and in Surakarta city particularly. The existence of potential sport tourism in the tourism development of Surakarta City has a positive impact on the number and duration of tourist visits, economic improvement, transportation services, and the tourism industry. Based on the above background, it is necessary to have a strategic formulation as an effort of PERSIS Solo to maximize the tourism attractiveness from the community. The increasing number of tourists will have an increasingly positive impact on the existence, quality of players, and club human resources to support the local government program of Solo City. This study aims to analyze the impact of Manahan Stadium renovation on the improvement of the PERSIS Solo sports tourism program using the SWOT method, by analyzing strengths and weaknesses of the internal side, analyzing opportunities and threats from the external side, and also formulating development strategies.

\section{Tourism}

Tourism is a phenomenon of the need for health and a change of atmosphere, a conscious assessment and growing (love) of natural beauty and in particular the increasing association of various nations and classes of human society as a result of the development of commerce, industry, trade, and the improvement of transportation means (Sivrikaya et al., 2018). Another definition explains that tourism is a trip from one place to another, temporary in nature, carried out individually or in groups, as an effort to find balance or harmony and happiness with the environment in the social, cultural, natural, and scientific dimensions (Astuti, 2015). A trip will be considered as a tourist trip if meets three requirements: temporary, voluntary which means that it does not occur due to coercion, and does not work which generates wages. Tourism objects form can be in the form of natural tourism objects such as mountains, lakes, rivers, beaches, sea, or in the form of building tourism objects such as museums, forts, historical heritage sites, and other forms of tourist objects. The implementation of tourism with a good managerial system can provide several benefits, including tourism plays an important role in the implementation of national unity with various people backgrounds from different regions and various customs, supporting State income with foreign 
currency, thereby reducing the deficit in the balance of payments, and tourism will help a region or country to have strong competitiveness and existence in the industry (Manhas et al., 2016).

As a strong social connector, sport can bring people together, expand and strengthen social relationships and networks, link people to resources, and provide them with a sense of belonging. Social relations are a basic determinant of health but are often lack for people marginalized by poverty, disease, discrimination, or even conflict. Sports can also be used to reduce social stigma experienced by marginalized groups, such as people with disabilities, people with HIV-AIDS, and others. When holding sport that involving these people with other members of normal society, it creates shared spaces and shared experiences that can help break the stigma of negative perceptions and allow people to focus on what they have in common rather than looking at caste. This is an important step in fostering emotional bonds between individuals and helps give a positive impression that sports have a unifying tourism attraction (Zeki Akinci \& Kasalak, 2016). Sport can play a valuable role as a communicator of education and health sectors for social community mobilization. In the sports sector by engaging and mobilizing high-profile elite athletes, professional sports clubs, and federations, this power of communication can be harnessed to provide critical health information and messages, model healthy lifestyle behaviors, and gather resources for health initiatives. At the community level, popular sports events offer a local platform for providing education and information on health that can serve as a starting point for movement in support of health promotion, vaccination, and control efforts (Jönsson \& Lewis, 2014).

\section{Special Interest Tourism}

Special interest tourism is an adventure that can be defined as a form of tourism travel carried out in a location that has unique and authentic physical attributes by emphasizing the elements of challenge, recreation, and the achievement of a tourist's desires through involvement/interaction with natural elements. Tourists who are involved in special interest tourism can be divided into two, the light group (Soft Adventure) which sees their involvement as more of a desire to try new activities, so the difficulty level of the challenges they are taking tends to be at a mild level or not too difficult and a heavy group (Hard Adventure) which sees their participation in an adventure of special interest tourism activity as more of a goal or main motivation, so they tend to be more actively and seriously involved in the activities they participate in. This group tends to look for products that offer challenge difficulties at levels above the average (Brotherton \& Himmetoğlu, 2015).

Special interest tourism rests on two main things, novelty-seeking, which means the motivation to search for unique and new objects and tourist attractions, or the search/exploration of new more challenging locations for the types of tourist attractions observed and quality seeking, which means the motivation to search for the forms of tourist objects and attractions that can provide meaningful value for tourists, value for enrichment or selfdevelopment, value for challenges or adventures, and value of new knowledge or insights. One of the characteristics of special interest tourism is product quality offered in the form of quality experience (Putra et al., 2020). Quality experience in special interest tourism is obtained through active participation. With the active participation of tourists, both physically and psychologically will feel the objects or tourist activities that they participate in (Adinegara et al., 2017).

\section{Sport Tourism}

Sports tourism is the main motivation for traveling, although elements of travel can amplify the overall experience. According to Undang-Undang No 3 of 2005 concerning the National Sports System stated that sports tourism is a sport carried out by people with passion and ability that grows and develops by conditions and cultural values of the local community for health, fitness, and joy (Woo-Sik Choi et al., 2016). Another definition says that sports tourism is a journey of people visiting certain places for a while in which there is a sports tourism attraction, both natural, cultural, and artificial, aiming to participate both actively and passively to fulfill pleasure or satisfaction. The main motive of tourists wanting to visit major sporting events is because of pleasure followed by the factor of finding entertainment and a place that aims to get satisfying and memorable personal experiences (Uvinha et al., 2018). Tourism for Sports (Sports Tourism), this type of tourism can be divided into two categories, namely the Big Sports Event which is one type of tourism carried out due to major sports events such as the Olympics Games, World Cup, and others. Furthermore, there is also a type of Sporting Tourism of the Practitioner, which is a type of sports tourism for those who want to practice and practice these sports empirically, such as mountain climbing, horse riding, etc. to gain self-experience (Nahar et al., 2019). 
The impact of existence of sport tourism has several findings, first finding is the types of work that are included in the main group and have an effect on sports tourism are services-based jobs or economic services such as sales, maintenance and personal care. The second finding implies the need to understand from which segments an area's population can make a profit from sports tourism. Event managers can create predictive models to determine the size of events and expenses needed to cover costs (Edrak et al., 2016). The existence of this researchbased positive information source can encourage for managers and government officials, as well as the community to express their potential ideas so that their area can become one of the main destinations for sports tourism (Jiménez-García et al., 2020).

\section{Gelora Manahan Stadium Solo}

Gelora Manahan was built in 1988, completed, and inaugurated in 1992 by Mrs. Tien Soeharto, the whole process was completed and used in 1998. The Gelora development project itself is handled by the consultant Tripanoto Sari, with the person in charge of Ir. Franky du ville. The idea of building the Manahan stadium was initiated by R. Maladi and then received a response from former president Soeharto. Sometimes people asked why the name R. Maladi is currently used for the Sriwedari stadium, not for the Gelora Manahan, this is because previously the ownership status of Gelora Manahan was not yet fully belonging to the Surakarta city government, but still owned by the Cendana family, which later gave the name Gelora Manahan according to the name of the place. The Gelora Manahan area is designed not only to host professional sports events but also to provide facilities for the entire Surakarta community, especially in sports activities. Apart from being a sports area for the people of Surakarta, the Gelora Manahan area is also a communal space, which is used as a place to gather together for various activities. For Indonesian football lovers, the name of Gelora Manahan is not a strange thing, this is because the Manahan stadium is one of the 8 best stadiums (national standard A) in Indonesia nowadays, and is often used to hold several important matches. Even though it received an A standard by BLI (Badan Liga Indonesia - the Indonesian league agency), but the current condition is still lacking in various things, such as the drainage system (current repair process), supporting facilities, etc., so some improvements are still needed (Putri, 2020).

The main building of the stadium consists of 3 floors (west and east side), and 2 floors (north and south side). The audience stands are divided into 3, namely: the economic stands in the east, the economy stands in the south and the north, as well as the VIP stands, and the VVIP (west side) with roof covers. The function of the main building of this stadium is not only for football matches but is used for athletic championships such as running, throwing discs, and others (you can see the running track in the picture above).Besides, the rooms designed according to the character of the stands are used for various things, including the stadium management room, the Surakarta KONI secretariat, services, and several martial arts training sites. Service facilities are arguably incomplete, for example, on the 2 nd and 3 rd floors on the east side, which are accessible to the economic stands, no toilets were provided, which caused some of the audience to urinate/defecate in the back of the stands, besides that there was also no canteen which led to the entry of hawkers into the stands which, although disturbing but also needed by some of the audience. Therefore, it is still necessary to re-plan or add basic facilities, the provision of facilities is divided according to the needs of the audience in each stand. The concept of distributing counters and entrances to the stands is very good in anticipating the crowds that may have caused riots, but the problem here is that the design of the door itself is less innovative, quite troublesome, and allows spectators to enter without tickets. The lighting in the Manahan stadium is good enough for a stadium in Indonesia, namely using 800 lux lamps, but by international standards, it is 1200 lux. Then for the very important scoreboard, it is not active, even if it is active it is still not standard because it should use a digital scoreboard. Meanwhile, the acoustic element for the audience is also not maximal, almost all viewers did not hear comments from the committee on the Commentary Seat (Ismawati \& Astuti, 2020).

\section{SWOT analysis}

SWOT analysis is one of the most widely recognized internal and external analysis instruments for companies environment. This analysis is based on the assumption that an effective strategy will minimize weaknesses and avoid threats. When applied accurately, this simple assumption has a positive and significant impact on the design of a successful strategy (Gürel \& Tat, 2017). Another definition states that SWOT analysis is an evaluation system of the overall internal environment (strengths and weaknesses) or external environment (opportunities and threats) which is based on the assumption that an effective strategy will create success for a company. The function of a SWOT analysis is to obtain information from situation analysis and separate it into 
internal issues (strengths and weaknesses) and external issues (opportunities and threats). The SWOT analysis will explain information that indicates strategic information that will help the company achieve its goals or provide an indication that there are obstacles that must be faced or minimized to meet the desired outcomes (Musanganya \& Sinumvayo, 2017). The strategic decision-making process is always related to the development of the mission, objectives, strategies, and policies of the company. Thus the strategic planner must analyze the company's strategic factors and issues related to strengths, weaknesses, opportunities, and threats in current conditions which are often referred to as situation analysis.

Strength is a resource of skills or other advantages relative to competitors and the market needs to be served by the company or organization. Strengths are specific competencies that provide a company with a comparative advantage in the market. Weakness is a limitation or deficiency in resources, skills, and capabilities that seriously hinders the effective performance of a company or organization. Facilities, financial resources, management capabilities, marketing skills, brand image can be sources of weakness.

Opportunities are important situations that benefit a company or organization. Important trends are one source of opportunity. Identification of market segments that were previously neglected, changes in competitive situations or regulations, changes in technology, and improved relationships with buyers or suppliers can provide opportunities for companies or organizations. Threat is an important unfavorable situation in a company or organizational environment. The threats are a major deterrent to the current position that organizations desire. The entry of new competitors, slower market growth, increased bargaining power of important buyers or suppliers, technological changes and new or revised regulations can pose future threats. In summary, opportunities in the external environment reflect possibilities where threats are potential constraints. Threats are the opposite meaning of the opportunity, thus it can be said that threats are environmental factors that are not beneficial to a business unit, if not addressed, threats will become obstacles to the business unit concerned both for the present and the future.

\section{METHOD}

The research type is descriptive qualitative research. Descriptive qualitative research aims to make a systematic, factual, and accurate description of a social or natural phenomenon (Igwenagu, 2016). The focus of the research is to identify the strengths, weaknesses, opportunities, and threats of the PERSIS Solo football club as an object of sport tourism, and to analyze the formulation of optimal strategy for developing PERSIS Solo football club as an object sports tourism. The location of this research is the Gelora Manahan Solo Stadium as the venue for the PERSIS Solo football club when home match. The second location is the PERSIS Solo football club office. The interview process will be conducted with management and supporters. The results of these interviews will be used as information for the evaluation and preparation of strategic formulations to support the PERSIS Solo football club as sports tourism. External environment interviews are included in the EFAS (External Strategic Factor Analysis Summary) matrix and internal environment interviews are included in the IFAS (Internal Strategic Factor Analysis Summary) matrix. After the internal and external strategic factors matrix is completed, the results will be included in a SWOT Matrix qualitative to formulate a competitive strategy (Musanganya \& Sinumvayo, 2017). The filling out of EFAS (External Strategic Factor Analysis Summary) matrix table and the IFAS (Internal Strategic Factor Analysis Summary) matrix table are as follows:

Table 1. Internal Strategic Factor Analysis Summary (IFAS)

\begin{tabular}{|c|c|c|c|}
\hline Strategic Factors & Weight & Rating & Score \\
\hline \multicolumn{4}{|c|}{ Internal } \\
\hline$(1)$ & $(2)$ & $(3)$ & $(4)=(2 \times 3)$ \\
\hline \multicolumn{4}{|c|}{ Strength } \\
\hline 1$)$ & & & \\
\hline 2$)$ & & & \\
\hline 3$)$ & & & \\
\hline \multicolumn{5}{|c|}{ Weakness } & \\
\hline 1$)$ & & & \\
\hline 2$)$ & & & \\
\hline 3$)$ & &
\end{tabular}

Source: (Ashutosh et al., 2020) 
Febrianur Ibnu Fitroh Sukono Putra, Diana Aqmala, Aflit Nuryulia Praswati: The Impact of Gelora Manahan Solo Renovation on Persis Solo Potential Sport Tourism

Table 2. External Strategic Factor Analysis Summary (EFAS)

\begin{tabular}{|c|c|c|c|}
\hline Strategic Factors & Weight & Rating & Score \\
\hline \multicolumn{4}{|c|}{ External } \\
\hline$(1)$ & $(2)$ & $(3)$ & $(4)=(2 \times 3)$ \\
\hline \multicolumn{4}{|c|}{ Opportunities } \\
\hline 1$)$ & & & \\
\hline 2$)$ & & & \\
\hline 3$)$ & & & \\
\hline \multicolumn{4}{|c|}{ Threat } \\
\hline 1$)$ & & & \\
\hline 2$)$ & & & \\
\hline 3$)$ & & & \\
\hline
\end{tabular}

Source: (Ashutosh et al., 2020)

The weights on the IFAS (Internal Strategic Factor Analysis Summary) and EFAS (External Strategic Factor Analysis Summary) tables are carried out on each factor from 0.0 (not important) to 1 (most important), then giving a rating from 1 to 4 for each external and internal factors about how important they are.

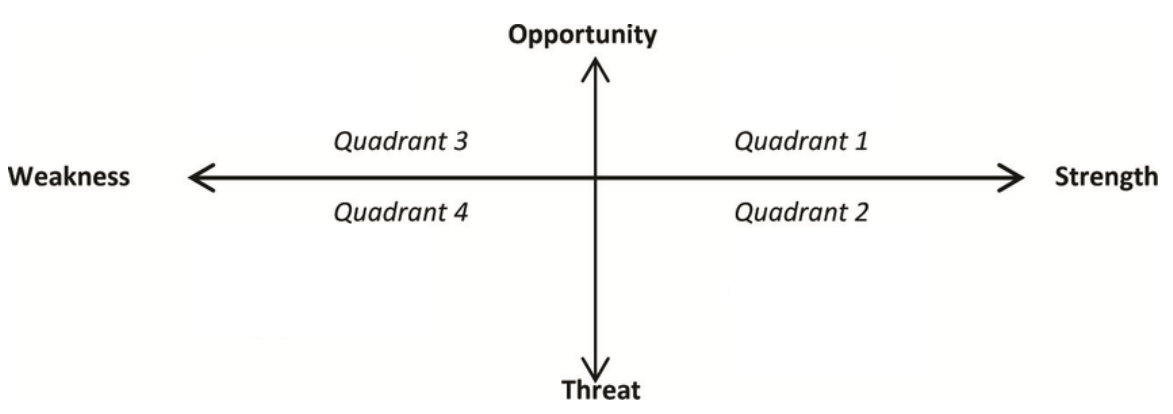

Figure 1. SWOT Analysis Quandrant

Source: (Gürel \& Tat, 2017)

Quadrant 1 is a very favorable situation. The company has opportunities and strengths so it can take advantage of existing opportunities optimally. The effective strategy that must be applied in this condition is to support an aggressive growth policy (Growth-oriented strategy). Meanwhile, in quadrant 2, despite facing various threats, this company still has strength from an internal perspective. The effective strategy that must be implemented is to manage internal strengths to take advantage of long-term opportunities with a diversification strategy (product or market). In quadrant 3 the company faces a very large market opportunity, they face several obstacles or weaknesses in internal capabilities. The business conditions in quadrant 3 are similar to Question marks in the Boston Consulting Group Matrix. The focus of the company's strategy is to minimize internal problems so it can seize potential market opportunities. Quadrant 4 is a very unfavorable situation because the company faces various threats and weaknesses on the internal side, so the effective strategy adopted is to minimize internal weaknesses to avoid various unfavorable threats in the future.

\section{RESULT AND DISCUSSION}

\section{SWOT ANALYSIS OF PERSIS SOLO AS SPORT TOURISM} Strength

Ownership of player human resources and good academy management will make management more confident in developing the club. PERSIS Solo has a venue with a fairly complete infrastructure due to the good cooperation with the relevant government so that the home matches are well facilitated. The availability of a mess for players' lodging and adequate club transportation. The fanaticism of the supporters and fans of PERSIS Solo, nicknamed Pasoepati, gave its aura and interest when visited Surakarta (Solo) because of its historical story. A 
strong brand image that PERSIS Solo is the most competitive Liga 2 team with other big teams such as PERSIJAP Jepara, PERSIK Kediri, PSMS Medan, and Mitra Kukar.

\section{Weakness}

The identified weakness factors of PERSIS Solo include management delays in making breakthroughs in the field of sports science and technology innovation, sports tourism product packages still do not have a wellprepared and comprehensive concept, for example, meet and greet with players and stadium tours both aimed for fans or general tourists. There has been no consistent collaboration with related agencies regarding sports tourism in Surakarta city.

\section{Opportunities}

Supporters' and fanatical loyalty in the form of support for PERSIS Solo is a culture inherent in the city of Surakarta (Solo). The development of increasingly sophisticated technology, especially in the mobile sector, will facilitate club management in expanding market share and tourism units in Surakarta, increasing public interest in sports especially football in Surakarta, and increasing the need for tourist destinations, as well as economic growth due to tourists on vacation and visiting Surakarta city. (Solo).

Threat

The first threat is the decline in PERSIS Solo achievements in the Indonesian football competition. Second, the inconsistency of Indonesian football regulations and frequent conflicts between competition participants and PSSI, as well as with the government. Determination of the match schedule that can change at any time.

\section{IDENTIFICATION OF STRATEGIC TOURISM SPORT WITH IFAS \& EFAS}

Table 3. Results of the Internal Strategic Factor Analysis Summary (IFAS) Matrix

\begin{tabular}{|l|l|l|l|}
\hline Factor & Weight $(\mathbf{W})$ & Rating $(\mathbf{R})$ & Weighted $(\mathbf{W x R})$ \\
\hline Strenght & 0,1 & 2 & 0,2 \\
\hline Player HR & 0,25 & 4 & 1,0 \\
\hline Infrastructure & 0,15 & 4 & 0,6 \\
\hline Fanaticism of fans & 0,1 & 3 & 0,3 \\
\hline Brand Image & $\mathbf{0 , 6}$ & \multicolumn{2}{|l|}{} \\
\hline Total & 0,2 & 3 & $\mathbf{2 , 1}$ \\
\hline Weakness & 0,15 & 4 & 0,6 \\
\hline Delayed in innovation & 2 & 0,1 \\
\hline The packaging of sport tourism packages is not good yet & 0,05 & $\mathbf{1 , 3}$ \\
\hline $\begin{array}{l}\text { The discourse on cooperation with related governments } \\
\text { is not yet integrated }\end{array}$ & 0,05 & $\mathbf{0 , 8}$ \\
\hline Total & $\mathbf{0 , 4}$ & & \\
\hline S-W gap & & \\
\hline
\end{tabular}

Source: Results of data processing, 2020.

Based on the weighting results in the IFAS table above, it can be identified that the internal position of PERSIS Solo is determined by the gap between strength $(S)$ and weakness $(W)$ which results in a value of 0.8 .

Table 4. Results of the External Strategic Factor Analysis Summary (EFAS) Matrix

\begin{tabular}{|l|l|l|l|}
\hline Factor & Weight $(\mathbf{W})$ & Rating $(\mathbf{R})$ & Weighted (WxR) \\
\hline Opportunities & 0,15 & 3 & 0,45 \\
\hline Loyalty of the public or tourists to football & 0,2 & 3 & 0,6 \\
\hline Development of mobile technology & 0,15 & 4 & 0,6 \\
\hline Increase in special interest tourism & 0,15 & 3 & 0,45 \\
\hline Economic growth & $\mathbf{0 , 6 5}$ & \multicolumn{2}{|l|}{} \\
\hline Total & \multicolumn{3}{|l|}{} \\
\hline Threat & 0,2 & 3 & 0,6 \\
\hline The decline in club performance & 4 & 0,4 \\
\hline Inconsistency of football competition regulations & 0,1 & \multicolumn{2}{|l}{} \\
\hline
\end{tabular}


Febrianur Ibnu Fitroh Sukono Putra, Diana Aqmala, Aflit Nuryulia Praswati: The Impact of Gelora Manahan Solo Renovation on Persis Solo Potential Sport Tourism

\begin{tabular}{|l|l|l|l|}
\hline Match schedule that can change at any time & 0,05 & 2 & 0,1 \\
\hline Total & $\mathbf{0 , 3 5}$ & & $\mathbf{1 , 1}$ \\
\hline O-T gap & & $\mathbf{1 , 0}$ \\
\hline
\end{tabular}

Source: Results of data processing, 2020.

Based on the weighting results in the EFAS table, it can be identified that the external position of PERSIS Solo is determined by the gap between opportunities $(\mathrm{O})$ and threat $(\mathrm{T})$ which results in a value of 1,0 .

The following is a picture of PERSIS Solo position after identifying the internal environment with IFAS and identifying the external environment with EFAS which shows that quadrant I is the best result of the SWOT analysis that has been carried out. These results provide recommendations that the potential for profitable growth for PERSIS Solo as a sports tourism object in Surakarta city can be done by utilizing existing strengths to maximize opportunities.

3. Support Strategy

$$
\text { Turn Around }
$$

Agressive

4. Support Strategy

Internal
Weakness

Defenssive

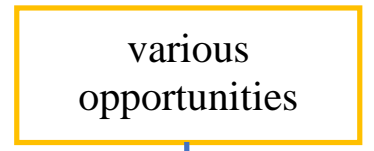

1. Support Strategy

Quadrant I

Quadrant III

2. Support Strategy

Internal strength

Figure 2. SWOT Analysis Quadrant Results

Growth strategy is the strategy most often sought and attempted by companies to continue to grow consistently so that the company can survive in the industry (Hunger \& Wheelen, 2012). Two reasons a growth strategy is so desirable, among others, that a growing company can easily minimize errors and inefficiencies compared to a stable company and a growing company also offers many opportunities for promotions and other interesting jobs to establish profitable partnerships. The results of the identification of internal and external factors showed positive results, which means that the strength of PERSIS Solo is relatively superior to its weaknesses in the potential to become an object of sport tourism, while the external environment has a greater chance of being successful than the threat. Therefore, PERSIS Solo can turn the potency into a better achievement and performance, so that the right direction for management policies to be implemented is by the S-O strategy to maximize the various opportunities that exist as in the following table: 
Table 5. Analysis of PERSIS Solo SWOT Matrix

\begin{tabular}{|c|c|c|}
\hline Internal Strategic Factor & Strength & Weakness \\
\hline $\begin{array}{l}\text { External Strategic Factor } \\
\text { Analysis Summary (EFAS) }\end{array}$ & $\begin{array}{l}\text { 1. HR Player } \\
\text { 2. Infrastructure } \\
\text { 3. The Fanaticism of } \\
\text { supporters through } \\
\text { attractions } \\
\text { 4. Brand image }\end{array}$ & $\begin{array}{l}\text { 1. Delay in innovation in the } \\
\text { field of sports science and } \\
\text { technology } \\
\text { 2. The packaging of sport } \\
\text { tourism packages is not } \\
\text { good yet } \\
\text { 3. The discourse on } \\
\text { cooperation with related } \\
\text { governments is not yet } \\
\text { integrated }\end{array}$ \\
\hline Opportunities & S-O Strategies & W-O Strategies \\
\hline $\begin{array}{l}\text { 1. Loyalty of the public or } \\
\text { tourists to football } \\
\text { 2. Development of mobile } \\
\text { technology } \\
\text { 3. Increase in special } \\
\text { interest tourism } \\
\text { 4. Economic growth }\end{array}$ & $\begin{array}{l}\text { 1. Providing the best } \\
\text { infrastructure on an } \\
\text { international scale will } \\
\text { increase the special interest } \\
\text { tourism of tourists from local } \\
\text { to international and support } \\
\text { the economic growth of } \\
\text { Surakarta City } \\
\text { The enhancement of } \\
\text { PERSIS Solo brand image } \\
\text { raises the potential for the } \\
\text { increasing loyalty of } \\
\text { Surakarta people to football } \\
\text { which is also supported by } \\
\text { the development of mobile } \\
\text { technology so that it is better } \\
\text { managed }\end{array}$ & $\begin{array}{l}\text { 1. Developing mobile } \\
\text { technology that provides a } \\
\text { choice of sports tourism } \\
\text { packages according to } \\
\text { consumer preferences is a } \\
\text { practical first step for the } \\
\text { club to attract tourists to } \\
\text { visit } \\
\text { The realization of } \\
\text { integrated cooperation with } \\
\text { the relevant government } \\
\text { will facilitate objectives } \\
\text { achievement in the } \\
\text { economic growth of } \\
\text { Surakarta in the tourism } \\
\text { sector }\end{array}$ \\
\hline Threat & Strategi S-T & Strategi W-T \\
\hline $\begin{array}{l}\text { 1. The decline in club } \\
\text { performance } \\
\text { 2. Inconsistency of } \\
\text { football competition } \\
\text { regulations } \\
\text { 3. Match schedule that can } \\
\text { change at any time }\end{array}$ & $\begin{array}{l}\text { 1. Improving the quality of } \\
\text { human resources for players } \\
\text { to maintain the stability of } \\
\text { the club's achievements and } \\
\text { also be able to boost the } \\
\text { club's achievement even } \\
\text { higher }\end{array}$ & $\begin{array}{l}\text { 1. Accelerating innovation in } \\
\text { the field of sports science } \\
\text { and technology will help } \\
\text { clubs improve their } \\
\text { achievements even better } \\
\text { 2. The realization of } \\
\text { cooperation between clubs } \\
\text { and related governments } \\
\text { will help clubs deal with } \\
\text { inconsistencies in football } \\
\text { competition regulations }\end{array}$ \\
\hline
\end{tabular}

Source: Processed data, 2020.

The results of the analysis in this study provide an increased understanding to Surakarta City government about the need to consider the tourism sector in the sports sector, especially football as an important part of the regional development program, and support the existence of PERSIS Solo in the national football industry.Besides, optimal management of football clubs and sports facilities will be one of the positive track records for Surakarta City as one of the potential cities that have a high selling value in the sports tourism sector, so if the country holds an event, Surakarta is one of the priority choices as a host that meets standards requirement. The complexity of Surakarta City tourism development program plan can be implemented more optimally because the football sector in Indonesia will experience rapid development and provide various kinds of positive impacts, especially from an 
Febrianur Ibnu Fitroh Sukono Putra, Diana Aqmala, Aflit Nuryulia Praswati: The Impact of Gelora Manahan Solo Renovation on Persis Solo Potential Sport Tourism

economic perspective if it is managed properly and has the potential to increase the existence of Surakarta city at the national and international levels. Some of the benefits and costs that will be obtained are as follows:

Table 6. Benefits and Costs of the Economic Perspective of Sports Tourism in Surakarta

\begin{tabular}{|l|l|l|}
\hline $\mathbf{N O}$ & BENEFITS & COSTS \\
\hline $\mathbf{1}$ & $\begin{array}{l}\text { Creating job opportunities and improving the } \\
\text { quality of regional human resources }\end{array}$ & $\begin{array}{l}\text { Increased license fees and prices for tourism } \\
\text { services }\end{array}$ \\
\hline $\mathbf{2}$ & $\begin{array}{l}\text { Bring increased income opportunities for } \\
\text { regions, companies and MSMEs }\end{array}$ & $\begin{array}{l}\text { Increased maintenance costs for various sports } \\
\text { facilities that have been built }\end{array}$ \\
\hline $\mathbf{3}$ & $\begin{array}{l}\text { Increase income tax and increase the potential for } \\
\text { tourist visits }\end{array}$ & $\begin{array}{l}\text { Increase in the cost of promoting tourism visits } \\
\text { increase the amount of investment in }\end{array}$ \\
\hline $\mathbf{5}$ & $\begin{array}{l}\text { Increase business networks on a regional to } \\
\text { national scale }\end{array}$ \\
\hline
\end{tabular}

Source: Processed data, 2020.

\section{CONCLUSION AND RECOMMENDATION}

Based on the results of this research about the potential of Surakarta City and PERSIS Solo sport tourism, the researcher can conclude there are several factors obtained have potential as strengths, weaknesses, opportunities, and threats to increase PERSIS Solo attractiveness as sport tourism. The strength factors which PERSIS Solo has as a sport tourism include improving infrastructure, human resources for players and academy coaches with optimally owned and managed, showcasing attractions from supporter creativity, and the famous PERSIS Solo brand image which can be used as an expand market potential strategies. Meanwhile, the weakness factors for PERSIS Solo as a potential for sports tourism include the delay of from management to breakthroughs innovation of sports science and technology facility, special tour packages for fans such as stadium tours, meet and great with club players. The PERSIS Solo opportunities factors as a potential sport tourism include the advancement of current technology development makes the management promote the club easier to the national level, the fanaticism of Surakarta football fans community, ease of accessibility from the Surakarta City government for sport tourists to attendance every match at the Gelora Manahan Solo Stadium, and increasing society in special interest tourism. The threat factors which include security facilities during matches, especially big match, television broadcast rights which are replaced by live streaming technological developments, and unstable situation of league competition. The results also show the potential of PERSIS Solo sport tourism is in quadrant I situation which aggressive growth (growth oriented strategy) because PERSIS Solo has good internal conditions (strength) so it can be used to maximize opportunities. The club management has best strategic formulation such as renovating sports infrastructure with international standards supported by sophisticated technology which can improve the economy of Surakarta City, increasing special interest tourism growth from domestic to foreign tourists, and increasing the loyalty of Surakarta society to football.

The limitations of this research include the object only use Indonesian League 2 club, so the results obtained, are less comprehensive. The suggestions for further research include researchers should have completely information database so it can further contribution to development of sport tourism in Indonesia. The suggestions for club management are develop new destinations and build a sport tourism unit based on security, cleanliness, healthy, beauty, hospitality, and full of memories spot. PERSIS Solo management should also adapt to use sports science and technology innovations such as coaching, medicine, match analysis, and performance analysis so it can improve club existence and competitiveness at national level. 


\section{REFERENCES}

Abujamous, I. M., Jawabreh, O. A. A., Jahmani, A., Alsarayreh, M. N., \& Harazneh, A. A. (2019). Developing Tourism Through Sports Events to Assist in The Rejuvenation of The Strategic Position of The Aqaba Special Economic Zone Authority (ASEZA). African Journal of Hospitality, Tourism and Leisure, 8(4), 1-14.

Adinegara, G. N. J., Suprapti, N. W. S., Yasa, N. N. K., \& Sukaatmadja, I. P. G. (2017). Factors That Influences Tourist's Satisfaction and Its Consequences. European Journal of Business and Management, 9(8), 39-50. www.iiste.org

Ashutosh, A., Sharma, A., \& Beg, M. A. (2020). Strategic analysis using SWOT-AHP: A Fibre Cement Sheet Company Application. Journal of Management Development, 39(4), 543-557. https://doi.org/10.1108/JMD-05-2019-0157

Astuti, M. T. (2015). Potensi Wisata Olahraga Dalam Meningkatkan Kunjungan Wisatawan. Jurnal Kepariwisataan Indonesia, 10(1), 31-40.

Brotherton, B., \& Himmetoğlu, B. (2015). Beyond Destinations-Special Interest Tourism. Anatolia: An International Journal of Tourism and Hospitality Research, 8(3), 11-30. https://doi.org/10.1080/13032917.1997.9687118

Edrak, B., Nor, Z. M., \& Maamon, N. M. (2016). Is Sport Tourism Policy Still Relevant To The Nation Economic Policy? International Journal of Consumer Policy, 6(1), 1-11.

Gürel, E., \& Tat, M. (2017). SWOT Analysis: A Theoretical Review. The Journal of International Social Research, $10(51), 1-13$.

Igwenagu, C. (2016). Fundamentals of Research Methodology and Data Collection (Issue June). LAP Lambert Academic Publishing. https://www.researchgate.net/publication/303381524_Fundamentals_of_research_methodology_and_ data_collection

Ismawati, E., \& Astuti, D. W. (2020). Kajian Mengenai Kompleks Stadion Manahan Antara Standarisasi Internasional dan Kebermanfaatan Bagi Masyarakat. SIAR: Jurnal Ilmiah Arsitektur, 2(1), 500-505.

Jiménez-García, M., Ruiz-Chico, J., Peña-Sánchez, A. R., \& López-Sánchez, J. A. (2020). A Bibliometric Analysis of Sports Tourism and Sustainability (2002-2019). Sustainability, 12(7), 1-18. https://doi.org/10.3390/su12072840

Jönsson, C., \& Lewis, C. (2014). Impacts of Hosting a Sport Event in Tourism High Season. RASAALA: Journal of Recreation and Society in Africa, Asia and Latin America, 5(1), 1-18.

Mandulangi, J., \& Towoliu, B. I. (2019). Exploring Local Community Perception to The Ecotourism Development Attraction at Tumpa Mount. International Journal of Applied Sciences in Tourism and Events, 3(2), 221-232.

Manhas, P. S., Manrai, L. A., \& Manrai, A. K. (2016). Role Of Tourist Destination Development In Building Its Brand Image: A Conceptual Model. Journal of Economics, Finance and Administrative Science, 21(40), 25-29. https://doi.org/10.1016/j.jefas.2016.01.001

Musanganya, I., \& Sinumvayo, J. P. (2017). SWOT Analysis As The Decision Making Support Tool To Conduct Competitive Analysis And Strategic Planning: An Update. Scholars Journal of Economics, Business and Management, 4(8), 509-518. https://doi.org/10.21276/sjebm

Nahar, F. H., Adha, M. A., Azizurrohman, M., Ulfi, I., \& Karimah, H. (2019). Determinants Of International 
Febrianur Ibnu Fitroh Sukono Putra, Diana Aqmala, Aflit Nuryulia Praswati: The Impact of Gelora Manahan Solo Renovation on Persis Solo Potential Sport Tourism

Tourism In Indonesia. JEJAK: Journal of Economics and Policy, 12(2), 298-317. https://doi.org/10.15294/jejak.v12i2.19440

Putra, F. I. F. S., Budiantoro, R. A., Luxfiati, B. A., \& Widawati, M. W. (2020). Consumer Satisfaction Behavior Bought Chinese Smartphone In The Official Store And Black Market In Soloraya. Jurnal Aplikasi Manajemen, 18(3), 588-596. https://doi.org/http://dx.doi. org/10.21776/ub.jam.2020. 018.03.19

Putri, L. R. (2020). Pengaruh Pariwisata terhadap Peningkatan PDRB Kota Surakarta. Cakra Wisata, 21(1), 43-49.

Rawe, A. S. (2018). Analisis Manajemen Dinas Pendidikan Pemuda Dan Olahraga Dalam Meningkatkan Prestasi Olahraga di Kabupaten Ende. SPORTIVE: Journal Of Physical Education, Sport and Recreation, 1(2), 1-17. https://doi.org/10.26858/sportive.v1i2.5622

Rudkin, S., \& Abhijit, S. (2017). The Impact of Football Attendance on Tourist Expenditures for the United Kingdom. Munich Personal RePEc Archive, 13(81427), 1-36. https://mpra.ub.unimuenchen.de/81427/2/MPRA_paper_81427.pdf

Seyidov, J., \& Adomaitienė, R. (2017). Factors Influencing Local Tourists' Decision-making on Choosing a Destination: a Case of Azerbaijan. Ekonomika, 95(3), 112-127. https://doi.org/10.15388/ekon.2016.3.10332

Sheng, C. W., \& Chen, M. C. (2016). Tourist Experience Expectations: Questionnaire Development And Text Narrative Analysis. International Journal of Culture, Tourism, and Hospitality Research, 7(1), 93-104. https://doi.org/10.1108/17506181311301390

Sivrikaya, K., Demir, A., \& Fisek, T. (2018). Innovation in Sports Management and The Role of Users , open Innovation And Sport-Based Entrepreneurship. Quest Journals Journal: Journal of Research in Business and Management, 6(17), 9-14. http://www.questjournals.org/jrbm/papers/vol6-issue1/B06010914.pdf

Uvinha, R. R., Chan, C.-S., Man, C. K., \& Marafa, L. M. (2018). Sport Tourism: A Comparative Analysis Of Residents From Brazil And Hong Kong Turismo Esportivo: Uma Análise Comparativa Entre Residentes Do Brasil E De Hong Kong Turismo Deportivo: Un Análisis Comparativo Entre Residentes De Brasil Y De Hong Kong. Brazilian Journal of Tourism Research, 12(1), 180-206. https://doi.org/10.7784/rbtur.v12i1.1374

Woo-Sik Choi, D., Shonk, D. J., \& Bravo, G. (2016). Development of a Conceptual Model in International Sport Tourism: Exploring Pre and Post Consumption Factors. International Journal of Sport Management, Recreation \& Tourism, 21, 21-47. https://doi.org/10.5199/ijsmart-1791-874x-21b

Zeki Akinci, \& Kasalak, M. A. (2016). Management of Special Interest Tourism in Terms of Sustainability Tourism. Journal of Global Issues and Trends in Tourism, 1(3), 185-196. 